\title{
Pre-PCR Processing in Bioterrorism Preparedness: Improved Diagnostic Capabilities for Laboratory RESPONSE NeTWORKS
}

Johannes Hedman, Rickard Knutsson, Ricky Ansell, Peter Rådström, and Birgitta Rasmusson

Diagnostic DNA analysis using polymerase chain reaction (PCR) has become a valuable tool for rapid detection of biothreat agents. However, analysis is often challenging because of the limited size, quality, and purity of the biological target. Pre-PCR processing is an integrated concept in which the issues of analytical limit of detection and simplicity for automation are addressed in all steps leading up to PCR amplification — that is, sampling, sample treatment, and the chemical composition of PCR. The sampling method should maximize target uptake and minimize uptake of extraneous substances that could impair the analysis-so-called PCR inhibitors. In sample treatment, there is a trade-off between yield and purity, as extensive purification leads to DNA loss. A cornerstone of pre-PCR processing is to apply DNA polymerase-buffer systems that are tolerant to specific sample impurities, thereby lowering the need for expensive purification steps and maximizing DNA recovery. Improved awareness among Laboratory Response Networks (LRNs) regarding pre-PCR processing is important, as ineffective sample processing leads to increased cost and possibly falsenegative or ambiguous results, hindering the decision-making process in a bioterrorism crisis. This article covers the nature and mechanisms of PCR-inhibitory substances relevant for agroterrorism and bioterrorism preparedness, methods for quality control of PCR reactions, and applications of pre-PCR processing to optimize and simplify the analysis of various biothreat agents. Knowledge about pre-PCR processing will improve diagnostic capabilities of LRNs involved in the response to bioterrorism incidents.

B IOTERRORISM, WHICH IS THE THREAT or use of biological agents by an individual or a terrorist group, and agroterrorism, which is a subset of bioterrorism targeting the agricultural sector by deliberately spreading animal and plant biothreat agents, are probably the most intersectoral and international challenges among chemical, biological, radiological, and nuclear (CBRN) threats. ${ }^{1,2}$ The deliberate spread of a biothreat agent in the environment or in the food chain requires proper diagnostic biopreparedness measures. $^{3,4}$ Consequently, diagnostic bioterrorism

Johannes Hedman, PhD, is employed as a specialist at the Swedish National Laboratory of Forensic Science (SKL) and holds a research position at Applied Microbiology, Lund University. Rickard Knutsson, PhD, is Director of Security Department, National Veterinary Institute (SVA), Uppsala, Sweden. Ricky Ansell, PhD, is employed as forensic advisor and senior reporting officer at the Swedish National Laboratory of Forensic Science (SKL). Birgitta Rasmusson, PhD, is employed as research director at the Swedish National Laboratory of Forensic Science (SKL) and holds a position as adjunct professor at Applied Microbiology, Lund University. Peter Rådström, PhD, is employed as professor Applied Microbiology, Lund University. 
response strategies must be available for overt and covert attacks, and these strategies should be based on lessons learned from previous attacks and incidents, planning scenarios, research activities, and validation and implementations of analysis methods. ${ }^{5}$ In addition, diagnostic preparedness against agroterrorism and bioterrorism requires interagency collaboration, which has resulted in the establishment of Laboratory Response Networks (LRNs) that can handle diagnostic challenges for many different sample types, including clinical, food, feed, air, water, and environmental samples. ${ }^{6,7}$ These laboratory networks for bioterror incidents have been established in many countries, including Australia, ${ }^{8}$ Canada, ${ }^{9}$ France, ${ }^{10}$ South Korea, ${ }^{11}$ Sweden, ${ }^{12}$ and the United States. ${ }^{13}$

Rapid and sensitive nucleic acid analysis methods are of vital importance in the response to a possible bioterrorism attack. The polymerase chain reaction (PCR) has become the backbone of contemporary diagnostic DNA analysis through its high target specificity, low limit of detection, and rapid analysis. In PCR, a specific DNA fragment is copied multiple times, ideally enabling detection and quantification of a bioterrorism agent even when only a few target cells are present. Several quantitative PCR (qPCR) assays have been developed for biopreparedness purposes, targeting different agents such as Bacillus anthracis, Francisella tularensis, and the smallpox virus. ${ }^{14-16}$ The use of multiplexing - that is, simultaneously analyzing 2 or more genetic markers in 1 reaction-has increased our ability to target several agents and even fingerprint specific species. ${ }^{14,17}$ Recently, universal assays targeting several agents have been proposed. ${ }^{18,19}$ The strength of this approach is that no prior assumptions on the type of agent need to be made, lowering bias as well as the need for several parallel analyses. The methods employ new detection and identification principles, as opposed to the "classic" principles using specific probes in $\mathrm{qPCR}$ and separation by fragment size in capillary electrophoresis. In one, the dissociation pattern of the DNA markers generated with universal primers was studied through high-resolution melting. ${ }^{18}$ This enabled the differentiation of 16S rRNA gene fragments from different organisms, giving a specific identity for each of 100 relevant bioterrorism agents. In the other, electrospray ionization mass spectrometry was applied for detection and approximate quantification of PCR products from several possible bioterrorism agents. ${ }^{19}$ There, specific primer pairs were used, and identification was based on the differing molecular weights of the amplicons. Nextgeneration sequencing is a powerful new technique with potential for highly discriminatory analysis of biothreat agents, and it has been shown to enable differentiation between individual strains of Bacillus anthracis and Yersinia pestis. ${ }^{20}$ The continuous development of specific PCR-based assays is an important preparedness measure against bioterrorism.

However, irrespective of the assay or detection principle used, all PCR-based analysis systems share some common challenges. In a bioterrorism crisis, decision makers need accurate and timely information, and the source is often impure biological samples with low levels of target. A rapid analysis process, with a high level of automation, will elevate the throughput. A great analytical challenge is the extraneous substances that pollute biological samples from the environment, impairing amplification and reducing the analytical limit of detection. ${ }^{21}$ Additionally, the concentration of target nucleic acids (ie, cells, spores, and viruses) is often low, so large samples need to be taken for subsequent concentration of nucleic acids.

Following sampling of surfaces, air, or water, a heterogeneous and dilute sample must be converted into a concentrated, amplifiable nucleic acid extract. Pre-PCR processing ${ }^{21,22}$ is an integrated concept in which the issues of analytical limit of detection and simplicity for automation are addressed in all steps leading up to PCR amplification (ie, sampling, sample treatment, and the chemical composition of PCR) (Figure 1). The sampling method should maximize target uptake and minimize uptake of PCR-inhibitory substances. In sample treatment, there is a trade-off between yield and purity, as extensive purification leads to DNA loss. ${ }^{23}$ Additionally, the buffers and reagents used in DNA extraction and purification should be compatible with the PCR in order to support amplification. ${ }^{24,25}$ A cornerstone of pre-PCR processing is to apply DNA polymerase-buffer systems that are tolerant to specific sample impurities, thereby increasing the analytical success rate and lowering the need for costly sample treatment procedures where DNA is lost. ${ }^{26,27}$ The overall aim of prePCR processing is thus to streamline the analysis process

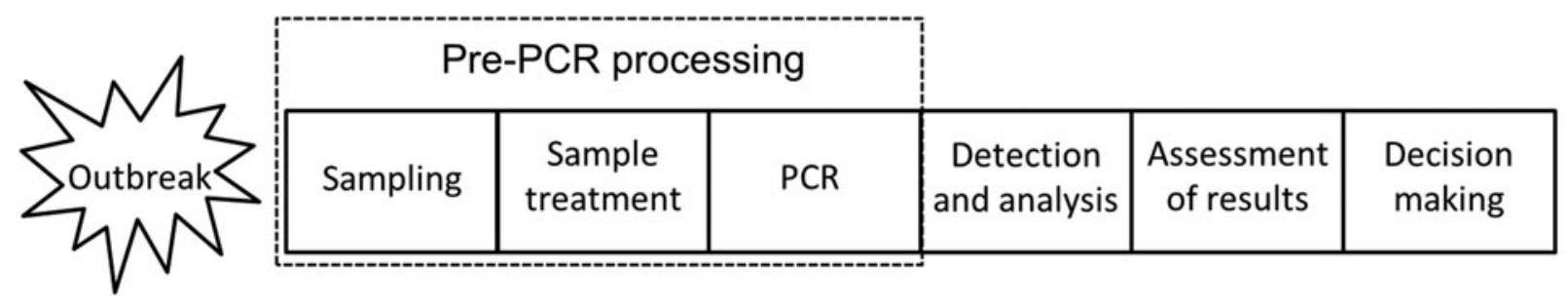

Figure 1. Overview of the DNA Analysis Process in Response to a Disease Outbreak or Bioterrorism Attack. The aim of pre-PCR processing is to provide a high analytical success rate in rapid, high-throughput analysis. A cornerstone of pre-PCR processing is to apply inhibitor-tolerant DNA polymerase-buffer systems in PCR, thereby lowering the need for costly sample treatment procedures where DNA is lost. 
and maximize the amount of amplifiable DNA in relation to the robustness of the applied PCR assay. The aim is not to generate the purest nucleic acid extract possible.

The issue of PCR inhibition has so far been most frequently discussed in the fields of microbial analysis of foods and feeds ${ }^{21,28,29}$ and in forensic DNA analysis ${ }^{30-32}$ due to the variable and complex nature of the targeted biological samples. In these fields, just as in agroterrorism and bioterrorism preparedness, relevant samples can be retrieved from any given background material, resulting in impure DNA extracts. Knowledge about PCR inhibitor effects and pre-PCR processing is important for existing LRNs in order to improve their diagnostic capabilities. Most diagnostic laboratories use commercially available DNA purification kits and PCR master mixes with proprietary content. This has benefits regarding standardization and quality control of reagents but has also turned PCR-based analysis into a black box: Troubleshooting is difficult when several parameters are unknown, and it is complicated to make appropriate improvements to the analysis systems.

This article is focused on the effects of PCR-inhibitory substances relevant in bioterrorism preparedness, methods for quality control of PCR reactions, and applications of pre-PCR processing to optimize the workflow and analytical success rate for various bioterrorism agents. The sections on PCR inhibition mechanisms, monitoring PCR inhibition, and robust DNA polymerase-buffer systems benefit from information from other scientific fields in which diagnostic PCR is employed: archaeology, clinical diagnostics, food and feed analysis, and forensics. The section on sampling and sample treatment is dedicated to challenges facing biopreparedness DNA analysis. Our aim is to provide laboratories involved in biopreparedness with knowledge on the limitations of diagnostic PCR, thereby enabling efficient sample processing, sound assessment of results, and competent troubleshooting.

\section{PCR Inhibitory Substances AND Their Mechanisms}

Some substances have been identified as PCR inhibitors and completely or partly characterized regarding their molecular PCR-inhibitory mechanism(s) (Table 1; for a more extensive review, see Hedman and Rådström ${ }^{22}$ ). Presence of PCR inhibitors results in impaired reaction kinetics, reduced limit of detection, and lowered reproducibility. In a bioterrorism incident, PCR-inhibitory substances that are not dealt with can have a devastating effect, hindering detection even though the specific agent is present in the sample. Any substance interfering with one or more of the molecular reactions involved in PCR (ie, denaturation, primer annealing, binding of polymerase to primer-DNA complex and primer extension) can have an inhibitory effect on amplification ${ }^{21}$ (Figure 2). Categor- izing PCR inhibitors is therefore a difficult task. As the exact mechanisms of most inhibitors are as yet unknown, the common classification is based on the affected targets, leading to 3 main groups of inhibitors: (1) DNA polymerase inhibitors, (2) nucleotide/nucleic acid inhibitors, and (3) fluorescence inhibitors (in qPCR). DNA polymerase inhibitors can either affect the enzyme directly (eg, by binding to its active site) or indirectly (eg, by chelating essential $\mathrm{Mg}^{2+}$ ions). Nucleotide or nucleic acid inhibitors can block amplification by binding to primers, singlestranded DNA (ssDNA), and/or double-stranded DNA (dsDNA) or by simply degrading nucleic acids. Fluorescence inhibitors interfere with the detection of amplicons in qPCR - for example, by forming precipitates blocking fluorescence, interacting with the fluorophore, or disturbing the probe's functionality or polymerase's $5^{\prime}-3^{\prime}$ exonuclease activity (Table 1).

Humic, fulvic, and tannic acids, as well as other polyphenolic compounds from the degradation of organic material, are potent PCR inhibitors that are present in, for instance, soil and bone. ${ }^{33,56-58}$ Humic acids may affect the DNA polymerase in 2 ways: by binding to its active site, thereby lowering enzymatic activity, and/or by binding to the enzyme elsewhere, introducing conformational changes that impair the binding of the polymerase to the primerDNA complex. ${ }^{34}$ However, humic acids are heterogeneous substances-in solution no 2 molecules are exactly alikeand purified humic acid purchased from a company may have different inhibitory properties compared to humic acids from real environmental samples. ${ }^{35}$ This heterogeneity may be the reason why different studies, using different preparations of humic acids and different PCR assays, have come to different explanations for their PCRinhibitory effects. Opel et al. ${ }^{32}$ argue that humic acid is a strict nucleic acid inhibitor, not affecting the DNA polymmerase, which binds sequence-specifically to DNA, thereby lowering the amount of available template and also affecting the melting temperature of the amplicons. Sutlovic et $\mathrm{al}^{34}$ also note that binding of humic acids to DNA could make it less accessible for amplification, but they view the impact as a combined DNA polymerase/nucleic acid effect, as shown by the ability to relieve inhibition by increasing the amount of DNA polymerase.

Suitable concentrations of mono- and polyvalent metal ions are important for successful PCR amplification, ensuring complete denaturation, efficient and specific primer annealing, and high DNA polymerase activity. $\mathrm{Ca}^{2+}, \mathrm{K}^{+}$, and $\mathrm{Mg}^{2+}$ are quite prevalent in cells and are thus released in DNA extraction. $\mathrm{Mg}^{2+}$ is a co-factor for the DNA polymerase and increases the affinity between the primers and DNA by lowering the electrostatic repulsion between the phosphate backbones of the strands. Increasing the amount of $\mathrm{Mg}^{2+}$ thereby generates a higher amplicon yield but decreases specificity. $\mathrm{Ca}^{2+}$ ions compete with $\mathrm{Mg}^{2+}$ for the binding sites on the polymerase, thereby inhibiting PCR by directly affecting polymerase activity. ${ }^{32,36} \mathrm{~K}^{+}$ions 
Table 1. Overview of PCR-Inhibitory Compounds and Ions

\begin{tabular}{|c|c|c|c|c|}
\hline Type of Inhibitor & Compound or Ion & Source & $\operatorname{Mechanism}(s)^{\mathrm{a}}$ & Reference(s) \\
\hline \multirow[t]{17}{*}{$\begin{array}{l}\text { DNA polymerase } \\
\text { inhibitors }\end{array}$} & $\mathrm{Al}^{3+}$ ions & $\begin{array}{l}\text { Sampling using } \\
\text { Al-shafted swabs }\end{array}$ & Alters ion composition & 43 \\
\hline & Bile salts & Feces & Direct effect on polymerase & 44,45 \\
\hline & $\mathrm{Ca}^{2+}$ ions & Bone, milk & $\begin{array}{l}\text { Competition with cofactor } \mathrm{Mg}^{2+} \text {, } \\
\text { alters ion composition }\end{array}$ & 32,36 \\
\hline & EDTA & Anticoagulant & Chelation of $\mathrm{Mg}^{2+}$ & 46 \\
\hline & Free radicals & $\begin{array}{l}\text { UV treatment } \\
\text { of PCR tubes }\end{array}$ & React with polymerase & $47-49$ \\
\hline & Fulvic acid & Soil & Binds to polymerase & 56 \\
\hline & $\begin{array}{l}\text { Heme/hematin/ } \\
\text { hemoglobin }\end{array}$ & Blood & $\begin{array}{l}\text { Release of iron ions, } \\
\text { competition with template, } \\
\text { lowers polymerase processivity }\end{array}$ & $32,50,51$ \\
\hline & Lactoferrin & Blood & Release of iron ions & 50 \\
\hline & Myoglobin & Muscle tissue & Release of iron ions & 52 \\
\hline & Phenol & Soil, DNA purification & $\begin{array}{l}\text { Denaturation of polymerase, } \\
\text { binding to polymerase }\end{array}$ & 53 \\
\hline & Phytic acid & Feces & $\begin{array}{l}\text { Chelation of } \mathrm{Mg}^{2+} \text { and alters ion } \\
\text { content if present as salt }\end{array}$ & 54 \\
\hline & Polymers & Chewing gum & Effect on polymerase activity & 27 \\
\hline & Polysaccharides & Feces & Bind to polymerase & 55 \\
\hline & Proteases (plasmin) & Milk & Degradation of polymerase & 95 \\
\hline & Tannic acid & Leather, plants, soil & $\begin{array}{l}\text { Interaction with polymerase, } \\
\text { chelation of } \mathrm{Mg}^{2+} \text { ions }\end{array}$ & 32,56 \\
\hline & Tobacco & Moist snuff & Effect on polymerase activity & 27 \\
\hline & Urea & Urine & $\begin{array}{l}\text { Prevents non-covalent bonding, } \\
\text { acts directly on polymerase and/or } \\
\text { prevents primer annealing }\end{array}$ & 136,137 \\
\hline \multirow{10}{*}{$\begin{array}{l}\text { Nucleic acid } \\
\text { inhibitors }\end{array}$} & Bilirubin & Feces & Competition with template & 50,56 \\
\hline & Cellulose & $\begin{array}{l}\text { Cigarette filter paper, } \\
\text { sampling filters, wood }\end{array}$ & $\begin{array}{l}\text { Binds to DNA, effect on } \\
\text { polymerase activity }\end{array}$ & $\begin{array}{l}26,27 \\
138-140\end{array}$ \\
\hline & Collagen & Bone & $\begin{array}{l}\text { Lowers polymerase processivity } \\
\text { by binding to DNA, alteration } \\
\text { of ion composition by } \\
\text { binding cations }\end{array}$ & 32,141 \\
\hline & Ethanol & DNA extraction & Precipitation of DNA & 46 \\
\hline & Formaldehyde & Preservative & $\begin{array}{l}\text { Interference with DNA and } \\
\text { DNA polymerase }\end{array}$ & 142 \\
\hline & Heparin & Anticoagulant & $\begin{array}{l}\text { Binds to DNA, competition } \\
\text { with template and/or interaction } \\
\text { with polymerase }\end{array}$ & 50,143 \\
\hline & Immunoglobulin $\mathrm{G}$ & Blood & $\begin{array}{l}\text { Formation of a complex } \\
\text { with single-stranded DNA }\end{array}$ & 38 \\
\hline & Isopropanol & DNA extraction & Precipitation of DNA & 46 \\
\hline & Melanin & Skin, hair & Binds to DNA, binds to polymerase & 32,94 \\
\hline & SYBR Green I & Detection dye & $\begin{array}{l}\text { Binds to dsDNA with high affinity, } \\
\text { binds to single-stranded DNA } \\
\text { (primers), affects polymerase activity }\end{array}$ & $39,70,144$ \\
\hline \multirow[t]{3}{*}{$\begin{array}{l}\text { Fluorescence } \\
\text { inhibitors }\end{array}$} & Humic acids & Soil, bone & $\begin{array}{l}\text { Quenches fluorescence, binds } \\
\text { to DNA polymerase and to } \\
\text { nucleic acids }\end{array}$ & $\begin{array}{l}32,34 \\
56-58\end{array}$ \\
\hline & Indigo dye & Denim fabric & $\begin{array}{l}\text { Hinders qPCR detection through } \\
\text { strong coloring, interferes } \\
\text { with SYBR Green I-DNA } \\
\text { interactions }\end{array}$ & 32 \\
\hline & Polymeric surfaces & $\begin{array}{l}\text { Miniaturized real-time } \\
\text { PCR instruments }\end{array}$ & Binding of detection dye & 145 \\
\hline
\end{tabular}

${ }^{a}$ Presumed mechanism(s). Inhibitors affecting the ion composition will affect the DNA polymerase (cofactor) and annealing properties of primers and probe system through nucleotides/nucleic acids and/or the qPCR fluorescence detection. 


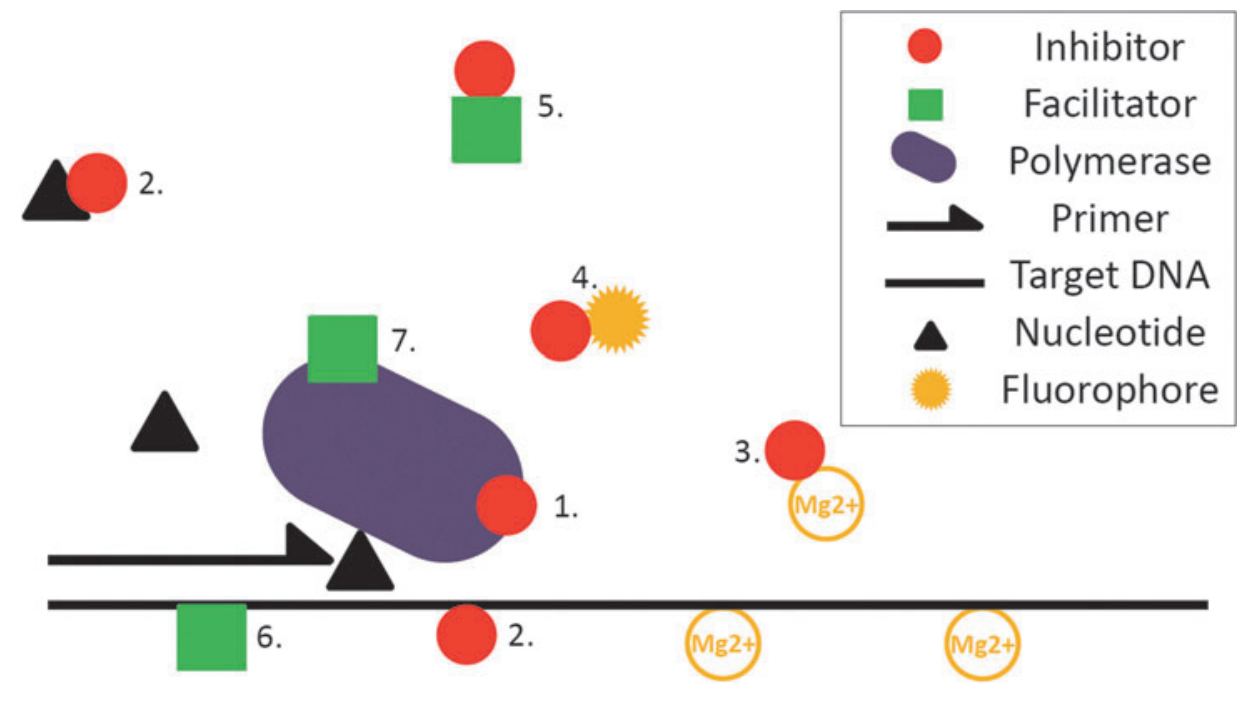

Figure 2. The Complexity of PCR Inhibition. A single PCR-inhibitory compound can affect the reaction in several ways, and different inhibitors can have different effects. Inhibitors may (1) bind to or degrade the DNA polymerase; (2) bind to nucleotides, primers, or the DNA template; (3) chelate cations; and/or (4) prevent the release of fluorescence from detection dyes. PCR facilitators may counteract inhibition by (5) serving as a target for inhibitors or bind to inhibitors; (6) stabilizing single-stranded DNA; and/or (7) improving the activity of the DNA polymerase.

are often used in the PCR buffer to ensure suitable ion content. Changing the amount of $\mathrm{K}^{+}$ions or introducing other ions (eg, $\mathrm{Na}^{+}$) may disturb amplification ${ }^{24}$ by affecting both DNA polymerase activity and the primer annealing conditions.

Nucleic acid inhibitors are molecules that affect the melting temperature of primers and DNA (eg, ions), bind to DNA, and/or alter the DNA conformation in such a way that primer annealing or extension is negatively affected. Nontarget DNA may inhibit amplification by sterically preventing the primers from annealing, or by providing nonspecific binding sites for the primers. ${ }^{37} \mathrm{Im}$ munoglobulin $G$ in blood plasma forms a complex with ssDNA, thereby affecting primer annealing and the level of free primers. ${ }^{38}$

The fluorescing dsDNA binding dye SYBR Green I, used for qPCR amplicon detection, may partly inhibit PCR when used at the recommended concentration. ${ }^{39}$ SYBR Green I fluoresces with high intensity when bound to dsDNA compared to the unbound dye, and increased fluorescence thereby signifies an amplicon increase. However, the exceptional DNA affinity of SYBR Green I can have an inhibitory effect by stabilizing dsDNA, thereby hindering denaturation. Dyes with lower affinity, such as SYTO-13 and SYTO-82, showed no PCR-inhibitory properties. ${ }^{39}$ SYBR Green I and various other DNAbinding dyes also bind ssDNA with different affinities, depending in part on the ion content in the buffer. ${ }^{40}$ This may lead to primer shortage and/or hinder primer annealing if too high dye amounts are used.

The detection system in qPCR is influenced by a specific set of inhibitors - that is, those that interfere with the fluorophores, probes, or fluorescence measurements. These inhibitors may not affect the actual amplification of DNA but can still produce false-negative results or underestimated DNA concentrations. Changes in the ion content of the reaction could affect the success of probe hybridization, causing a lowered fluorescence signal. Molecules may interfere with the DNA polymerases' $5^{\prime}-3^{\prime}$ exonuclease activity, thereby inhibiting TaqMan probe hydrolysis. ${ }^{41}$ Humic acids quench the fluorescence of SYBR Green I, probably by binding to the fluorophore or by collisional quenching. ${ }^{42}$ Surface-bound SYBR Green I fluoresces most, and humic substances may also prevent surface binding. Hematin in blood and indigo dye may interfere with the binding of SYBR Green I to dsDNA or have a quenching effect. ${ }^{32}$ Materials that are strong in color may also interfere with fluorescence detection by simply obscuring the signal.

\section{MONITORING PCR INHIBITION in Biopreparedness Analysis}

An internal amplification control (IAC) (ie, an "alien" DNA fragment of known concentration) may be included in biopreparedness QPCR assays to monitor the quality of the reactions and to avoid false-negative results. ${ }^{59,60}$ The presence of PCR inhibitors or other problems related to amplification can result in either complete failure to amplify the IAC or an elevated IAC quantification cycle $\left(\mathrm{C}_{\mathrm{q}}\right)$ value.

For absolute quantification, dilution series of pure DNA with known concentrations are analyzed to obtain a standard curve. The standard curve is then used to calculate the 
DNA concentrations of the samples. For correct DNA quantification, it is important that the reaction kinetics of the sample be the same as for the DNA used to obtain the standard curve. Concentrations could be seriously underestimated if the amplification efficiency of the sample is lower than for the DNA standard (eg, due to PCR inhibition). ${ }^{61}$ Tichopad et al. ${ }^{62}$ proposed a bivariate kinetic outlier detection (KOD) method to evaluate the kinetics of individual reactions by comparing them with ideal standard reactions, in which first and second derivative maxima of a fitted sigmoidal model are calculated. ${ }^{62,63}$ The 2 values are then combined to give $1 \chi^{2}$ distributed value. High values imply that the reaction kinetics are significantly different from the kinetics of pure reactions. The method can be used to identify kinetic outliers in quantification - that is, samples that may not be properly quantified using the standard curve - or to estimate the level of inhibition in a reaction. The KOD method has been shown to be more reliable in identifying reactions affected by PCR inhibitors than various methods for calculating amplification efficiency from individual amplification curves. ${ }^{62}$ For a review of KOD methods, see Bar et al. ${ }^{64}$

Inhibitory compounds that have a direct effect on DNA, lowering the amount of available template, may impair amplification and elevate $C_{q}$ values without affecting amplification efficiency or being flagged as kinetic outliers. ${ }^{32}$ Thus, an IAC is beneficial in the bioterrorism agent qPCR assay to ensure that all inhibitory effects are detected. When designing an appropriate IAC, several criteria must be considered.

The IAC primer sites may be equal to those of the target, ${ }^{65}$ or they may be different, creating a need for separate primer pairs. ${ }^{66}$ In the first case, there is competition for the primers, affecting the amplification efficiency of both the template and the IAC. Incorporating a second primer pair may increase the risk of primer-dimer formation and nonspecific primer annealing.

If the IAC concentration is too high, the amplification of the target may be negatively affected. The appropriate number of IAC molecules depends on the assay, but generally low numbers are preferable-for example, from around 20 to 100 copies per reaction. ${ }^{65,67,68}$ Since the amplification of target DNA competes with IAC amplification, even when different primer pairs are used, the $\mathrm{C}_{\mathrm{q}}$ value for the IAC may be elevated when levels of target DNA are high, generating a false inhibitory effect. ${ }^{69}$

Amplification of the IAC should ideally be somewhat more easily disturbed by impurities than the target. The size of the IAC is important in this respect, since shorter fragments are generally more readily amplified in the presence of inhibitors than longer ones. ${ }^{70}$ An IAC amplicon slightly longer than the target is therefore recommended. ${ }^{65}$

IACs can also be applied in multiplex biomarker assays for conventional PCR with capillary electrophoresis detection. Zahra et al. developed 2 IAC fragments, 90 and 410 base-pairs, for a forensic DNA typing system with target amplicons ranging from 100 to 350 base-pairs. ${ }^{71}$ The longer IAC fragment proved to be more sensitive to inhibition from heme and humic acid compared to the shorter one, making the ratio between their respective fluorescence peak heights a measure of the inhibitory effect. Other than adding IACs to multiplex conventional PCR assays, each marker's electropherogram peak height can be used as a measure of analytical quality. ${ }^{72,73}$ The intensity of the allelic peaks, corresponding to the number of generated amplicons, and the balance between peaks give information on the impact of PCR inhibition. Intensity and balance can be presented as separate measures ${ }^{73}$ or combined to 1 measure using principal components analysis. ${ }^{26,72}$

\section{INHIBITOR-TOLERANT DNA Polymerase-Buffer Systems}

DNA polymerases from different sources differ in their tolerance to various PCR inhibitors, ${ }^{24}$ making the choice of DNA polymerase a vital part of setting up a PCR assay for detection and quantification of a certain bioterrorism agent in a specific environment. Additionally, the composition of the PCR buffer (ie, the $\mathrm{pH}$, ion content, and presence of PCR facilitators) affects amplification efficiency and PCR inhibitor-tolerance. ${ }^{25,74,75}$ These facts are often overlooked, and most end-user laboratories and researchers simply use the DNA polymerase-buffer system that is provided with the commercial kit or master mix they purchase, possibly affecting the limit of detection negatively. This section highlights the differences in PCR inhibitor-tolerance between different DNA polymerases, and the possibilities to increase analytical robustness by optimizing the content of the PCR buffer.

\section{Inhibitor-Tolerance of Thermostable DNA Polymerases}

High-quality thermostable DNA polymerases are a vital component of PCR. ${ }^{76}$ Any compound that interferes with their enzymatic activity will reduce the formation of specific PCR products. ${ }^{24,26,51}$ The DNA polymerase obtained from the thermophilic bacterium Thermus aquaticus (Taq) and its commercial derivatives are most widely used because of their high thermostability and good processability, ${ }^{77}$ but also because of availability and "old habit." Polymerases from a range of other organisms are also commercially available (eg, Thermus thermophilus [Tth], Thermus flavus $[T f]$, and Pyrococcus furiosus $[P f u]$ ), differing in catalytic properties (eg, having $3^{\prime}-5^{\prime}$ and/or $5^{\prime}-3^{\prime}$ exonuclease activity), extension rates, and fidelity. ${ }^{77,78}$

Hot-start DNA polymerases provide higher target amplicon yields than natural variants ${ }^{79,80}$ and can be more tolerant to impurities than other polymerases; ${ }^{35}$ this is partly explained by the continuous release of active 
polymerase throughout PCR cycling. Hot-start DNA polymerases are inactive at room temperature, either by binding of a heat-sensitive antibody to the active site of the polymerase $^{81}$ or by covalently binding a blocking molecule to lysine residues within and outside the active site, ${ }^{82}$ and they are activated by the heat in the initial denaturation step.

Increasing the amount of DNA polymerase is a means to titrate out polymerase inhibitors and has been shown to relieve inhibition caused by humic acid. ${ }^{33}$ However, the success of this approach is limited and depends on the amounts and types of inhibitors present. When analyzing crime scene samples of various types, doubling the amount of AmpliTaq Gold improved amplification for moist snuff, but no or minor improvements were seen for chewing gum and cigarette butts, ${ }^{27}$ indicating that inhibitors in the latter had a stronger negative effect on the DNA polymerase activity.

Several DNA polymerases originating from Taq are more susceptible to inhibitors found in blood, bone, foods, feces, and soil than Tth-based polymerases. ${ }^{24,52,53,83}$ Moreover, notable inhibitor-tolerance differences have been found between different Taq-based polymerases. ${ }^{26,27,83,84}$ The commonly used polymerase AmpliTaq Gold performs poorly in the presence of inhibitors from various substances, including blood, soil, and bone. ${ }^{24,52,83,84}$ For over a decade, AmpliTaq Gold was the standard DNA polymerase in forensic DNA analysis. However, when analyzing impure crime scene samples, such as cigarette butts and swabs from cans and bottles, 3 alternative DNA polymerases (Bio-X-Act Short, ExTaq Hot Start, and PicoMaxx High Fidelity) performed significantly better than AmpliTaq Gold, generating a higher number of complete DNA profiles. ${ }^{26}$

During recent years, new DNA polymerase variants have been developed with the objective of improving PCR inhibitor-tolerance. Using a protein engineering approach, random mutations have been introduced into natural Taq and its N-terminally truncated version Klen Taq. ${ }^{84,85}$ Subsequent screening for inhibitor-resistant properties led to the development of DNA polymerases with improved tolerance to blood and soil components, one bearing the commercial name OmniTaq. However, although OmniTaq is tolerant to various inhibitory compounds, it does not necessarily provide any improvements compared to natural Taq polymerase in terms of limit of detection and general amplification efficiency. ${ }^{26}$

Molecular breeding and compartmentalized self-replication have been used to engineer chimeric, inhibitor-tolerant DNA polymerases with elements from various Thermus polymerases (eg, Taq, Tth, T. oshimai, and T. brockianus). ${ }^{35}$ One of these engineered DNA polymerases, called 2D9, contained 81 mutations compared to natural Taq and showed considerable tolerance to inhibitors present in soil and bone. Since inhibitors such as these are likely to form colloids, it was suggested that 2D9 may interact less with colloids. However, 2D9 was not successful in the analysis of whole blood, indicating that it may not be suitable for broad-range PCR-inhibitory bioterrorism samples.

Blending DNA polymerases is one way of achieving desirable properties in a PCR assay-for example, to improve the fidelity of Taq polymerase assays by adding a small amount of a polymerase with proofreading capacity ( $3^{\prime}-5^{\prime}$ exonuclease activity), such as $P f u$ polymerase. ${ }^{86,87}$ Combining 2 inhibitor-tolerant DNA polymerases with complementary properties has been shown to provide a DNA polymerase-buffer system with broader-range inhibitor-resistant properties. ${ }^{27}$ Apart from complementarity, the DNA polymerases in the blend (ExTaq Hot Start and PicoMaxx High Fidelity) exhibit synergy: Not only do the DNA polymerases function together; they amplify each other's performance in impure reaction conditions.

\section{Relieving Inbibition by Modifying the PCR Buffer}

For most Taq polymerases, a Tris buffer with $\mathrm{pH} 8.3$ (measured at room temperature) is recommended. Elevating the $\mathrm{pH}$ of the Tris buffer to 9.0 or more has been shown to relieve inhibition caused by leukocytes. ${ }^{88}$ Replacing the Tris buffer with a zwitterionic buffer such as tricine may improve inhibitor-tolerance, as shown for direct amplification of whole blood. ${ }^{89}$

Increasing the amount of $\mathrm{Mg}^{2+}$ ions can counteract inhibition from chelating agents, DNA intercalating dyes, and $\mathrm{Ca}^{2+}$ ions. ${ }^{36,90}$ Apart from optimizing the core reagents, PCR facilitators can be added to the buffer. Various facilitators have been used to increase the specificity and fidelity of PCR, and several substances have the capacity to relieve PCR inhibition (Figure 2, Table 2).

Bovine serum albumin (BSA) is the most commonly used PCR facilitator, and it is added to the buffers supplied with several commercial DNA polymerases. BSA is a bloodtissue transport protein that binds fatty acids (lipids) and other organic molecules. Its excellent binding capacity makes it suitable for relieving various types of PCR inhibition. BSA has been suggested to bind inhibitory compounds such as heme, phenols, and melanin, ${ }^{25,56,94}$ thereby protecting the polymerase. BSA may also act as a competitive target for proteases. ${ }^{95}$ A range of different BSA concentrations have been used to counteract inhibition, and the optimal concentration depends on the assay and the nature of the sample (Table 2). BSA has been shown to outperform other facilitators such as dimethyl sulphoxide (DMSO), polyethylene glycol (PEG), and Tween 20 for removing inhibitory effects from blood, feces, and meat samples. $^{25}$

Different types of PCR facilitators may provide complementary or synergistic effects. Two recently developed facilitator blends have been shown to increase the tolerance to blood and soil inhibitors. ${ }^{40,96}$ Both blends apply the 
Table 2. PCR Facilitators Used to Alleviate Inhibition

\begin{tabular}{|c|c|c|c|c|c|}
\hline $\begin{array}{l}\text { Type of } \\
\text { Facilitator }\end{array}$ & Facilitator & Concentration & Source(s) of Inhibition & $\operatorname{Mechanism}(s)^{\mathrm{b}}$ & Reference(s) \\
\hline \multirow[t]{6}{*}{ Protein } & BSA & $0.1-1.28 \mathrm{~g} / \mathrm{L}$ & $\begin{array}{l}\text { Bile salts, feces, } \mathrm{FeCl}_{3} \text {, } \\
\text { fulvic acid, hemoglobin, } \\
\text { humic acid, } \\
\text { immunoglobulin G, } \\
\text { lactoferrin, meat, } \\
\text { melanin, proteases, } \\
\text { saliva stains, tannic acid, } \\
\text { waste water sludge }\end{array}$ & $\begin{array}{l}\text { Binding of inhibitory } \\
\text { compounds such } \\
\text { as heme, fatty acids, } \\
\text { melanin and phenol; } \\
\text { competitive target } \\
\text { for proteases }\end{array}$ & $\begin{array}{l}25,38 \\
44,50,56 \\
91-95\end{array}$ \\
\hline & Casein & $0.01 \%(\mathrm{w} / \mathrm{v})$ & $\begin{array}{l}\text { Bile salts, humic } \\
\text { material, phenols }\end{array}$ & $\begin{array}{l}\text { Binding of inhibitory } \\
\text { compounds }\end{array}$ & $44,146,147$ \\
\hline & $\mathrm{Gp} 32^{\mathrm{c}}$ & $0.02-0.15 \mathrm{~g} / \mathrm{L}$ & $\begin{array}{l}\text { Feces, } \mathrm{FeCl}_{3} \text {, fulvic acid, } \\
\text { hemoglobin, humic acid, } \\
\text { lactoferrin, meat, } \\
\text { tannic acid }\end{array}$ & $\begin{array}{l}\text { Enabling annealing } \\
\text { by stabilizing single- } \\
\text { stranded DNA; binding } \\
\text { to inhibitory } \\
\text { compounds }\end{array}$ & $\begin{array}{l}25,37,38 \\
56,148\end{array}$ \\
\hline & $\begin{array}{l}\text { Lima bean } \\
\text { trypsin } \\
\text { inhibitor }\end{array}$ & $0.02 \mathrm{~g} / \mathrm{L}$ & Blood & $\begin{array}{l}\text { Inhibition of protease } \\
\text { activity }\end{array}$ & 24 \\
\hline & Phytase & $50 \mathrm{U} / \mathrm{mL}$ & Phytic acid in feces & $\begin{array}{l}\text { Catalyzing the } \\
\text { hydrolysis of } \\
\text { phytic acid }\end{array}$ & 54 \\
\hline & $\begin{array}{l}\text { Protease } \\
\text { inhibitor }\end{array}$ & $1 \mathrm{x}$ & Feces & $\begin{array}{l}\text { Inhibition of } \\
\text { protease activity }\end{array}$ & 25 \\
\hline \multirow[t]{2}{*}{$\begin{array}{l}\text { Non-ionic } \\
\text { detergent }\end{array}$} & $\begin{array}{l}\text { NP-40 } \\
\text { (Igepal) }\end{array}$ & $0.8 \%$ & Blood & $\begin{array}{l}\text { Improves cell lysis when whole } \\
\text { blood is used in PCR }\end{array}$ & 96 \\
\hline & Tween 20 & $0.1-0.5(\mathrm{w} / \mathrm{v})$ & $\begin{array}{l}\text { Feces, phenolic } \\
\text { compounds, plant } \\
\text { polysaccharides }\end{array}$ & $\begin{array}{l}\text { Reduction of false } \\
\text { primer extension } \\
\text { terminations }\end{array}$ & $25,149-151$ \\
\hline \multirow[t]{3}{*}{$\begin{array}{l}\text { Organic } \\
\text { solvent }\end{array}$} & DMSO & $2-10 \%$ & GC-rich fragments & $\begin{array}{l}\text { Destabilizing nucleotide base } \\
\text { pairing, lowering of DNA } \\
\text { melting temperature }\end{array}$ & 152,153 \\
\hline & Formamide & $0.01 \%(\mathrm{w} / \mathrm{v})$ & $\begin{array}{l}\text { Bile salts, } \\
\text { facilitate amplification } \\
\text { for assays with } \\
\text { insufficient thermal } \\
\text { denaturation }\end{array}$ & $\begin{array}{l}\text { Destabilizing nucleotide } \\
\text { base pairing, lowering } \\
\text { of DNA melting } \\
\text { temperature }\end{array}$ & 44,154 \\
\hline & Propanediol & $1 \mathrm{M}$ & Hemoglobin & $\begin{array}{l}\text { Destabilizing nucleotide } \\
\text { base pairing, lowering } \\
\text { of DNA melting } \\
\text { temperature }\end{array}$ & 40 \\
\hline \multirow{4}{*}{$\begin{array}{l}\text { Biologically } \\
\text { compatible } \\
\text { solute }\end{array}$} & Betaine & $\begin{array}{l}5.9-11.7 \% \\
(\mathrm{w} / \mathrm{v})\end{array}$ & Hemoglobin & $\begin{array}{l}\text { Improves thermostability } \\
\text { of DNA polymerase }\end{array}$ & 25,38 \\
\hline & L-Carnitine & $0.06-0.5 \mathrm{M}$ & Blood & $\begin{array}{l}\text { Protects reaction } \\
\text { from osmotic stress }\end{array}$ & 96 \\
\hline & Sorbitol & $2-30 \%(w / v)$ & Blood & Neutralizes inhibitors & 89 \\
\hline & Trehalose & $2-30 \%(w / v)$ & $\begin{array}{l}\text { Blood, hemoglobin, } \\
\text { tobacco }\end{array}$ & $\begin{array}{l}\text { Lowering of DNA melting } \\
\text { temperature, improves thermal } \\
\text { stability of DNA polymerase, } \\
\text { neutralizes inhibitors }\end{array}$ & $\begin{array}{l}40,89,96 \\
155\end{array}$ \\
\hline Polymer & PEG 400 & $5-15 \%$ & $\begin{array}{l}\text { Blood, feces, } \\
\text { polysaccharides }\end{array}$ & $\begin{array}{l}\text { Stabilizes DNA } \\
\text { polymerase }\end{array}$ & $25,150,152$ \\
\hline Polyamine & Spermidine & $0.5-4 \mathrm{mM}$ & Blood, feces & $\begin{array}{l}\text { Binding to DNA, may stimulate } \\
\text { DNA polymerase activity }\end{array}$ & 89,156 \\
\hline
\end{tabular}


same osmoprotectant, the disaccharide trehalose, as a key component. Trehalose was complemented with the detergent NP-40 and L-carnitine, or propanediol. However, positive interactions between PCR facilitators depend on their nature and cannot always be expected. ${ }^{25}$ On the contrary, combining facilitators may induce inhibition. ${ }^{119}$ Overloading of facilitators will also inevitably lead to inhibition. ${ }^{46,97}$

\section{Biothreat Agent Sampling, Sample Treatment, and PCR}

\section{Sampling}

Prior to the 2001 terrorist actions with envelopes containing Bacillus anthracis spores in the US postal system, there were no standardized policies for sampling procedures for bioterrorism preparedness. ${ }^{98}$ Following these events, substantial work has been focused on developing and evaluating sampling methods for spores on various surfaces, for PCR-based analysis ${ }^{99,100}$ as well as for classical microbial analysis. ${ }^{98-102}$ Recently, standards for "Sample Collection and Swab Sample Collection of Visible Powders Suspected of Being Biothreat Agents from Nonporous Surfaces" and "Operational Guidelines for Initial Response to a Suspected Biothreat Agent" have been developed. $^{103,104}$

Cotton swabs are commonly used as a part of the PCR analysis chain in all fields applying nucleic acid analysis. A pre-PCR processing protocol with cotton swabs has been developed for Yersinia enterocolotica. ${ }^{105}$ However, cotton swabs and swabs of other materials are limited by the size of the surface they can cover. When screening for possible bioterrorism agents, large surface areas must be sampled to avoid false-negative results, meaning that ordinary swabs are not ideal. A biological sampling kit (BiSKit) applying a thick foam material enables sampling of a surface area of $1 \mathrm{~m}^{2}$ (wood laminate and metal) for subsequent PCR analysis. ${ }^{100}$ BiSKit foam performed better than swabs made of cotton and foam for both surface types, explained in part by the smaller area covered by the swabs (around $100 \mathrm{~cm}^{2}$ ). Gauze can also be used for sampling of large surfaces, as shown for carcass sampling. ${ }^{106}$ Tape lifting is gaining popularity in forensic DNA analysis and has been successfully used for sampling of human cell material from diverse items such as clothes, skin, handguns, and shoe insoles. ${ }^{107-111} \mathrm{~A}$ piece of adhesive tape is pressed against the object a number of times, covering a larger area than a swab. The cells adhere to the tape, which is subsequently placed in a tube for DNA extraction. Tape lifting could possibly be applied in bioterrorism preparedness for sampling of inert surfaces.

The aim of surface sampling is to efficiently release and recover cells, spores, and viruses. However, impurities will also be released and collected in the process. Depending on the sampling method, more or fewer impurities will be absorbed, affecting the amplifiability of the generated extracts. In a study comparing surface decontamination strategies, a swipe sponge and a foam swab gave higher levels of PCR inhibition compared to a Heavy Wipe cloth. ${ }^{112}$ Sampling efficiency can be affected by the sampling method but also by interactions between the surfaces and the microbes. For virulent strains of Bacillus anthracis and Yersinia pestis, the sampling efficiency was lower for hydrophobic surfaces (vinyl and plastic) compared to hydrophilic surfaces (glass and stainless steel). ${ }^{113}$ It was suggested that this was due to specific cell surface receptors or capsular material, as nonvirulent strains did not show any differences between the surface types.

In direct sampling, as opposed to the indirect swabbing procedures, a piece of the material carrying the target cells is directly submitted to sample treatment. Examples are soil, water, and fabrics. Generally, direct sampling provides a high DNA yield but often leads to problematic levels of PCR inhibitors. ${ }^{57,114}$

Sampling of large air volumes can be performed by filtration $^{115}$ or by applying instruments that concentrate the air content into a small amount of liquid, such as the SKC Biosampler and the SpinCon system. ${ }^{115,116}$ If infectiousness of viruses needs to be studied, liquid sampling is preferable. ${ }^{115}$ Inevitably, microorganisms naturally present in the environment, and dust and pollutants will also end up in the concentrated air samples. This can have a detrimental effect on analytical limit of detection. In a study employing liquid air samples spiked with possible bioterrorism agents such as Coxiella burnetii and Yersinia pestis, the environmental background elevated the limit of detection up to $1 \mathrm{log}$ unit depending on the assay. ${ }^{116}$ However, some of the assays tested were not affected by the background, although only a simple bead beating procedure was applied.

\section{Sample Treatment}

Sample treatment generally includes (1) eluting cells/spores from the sampling material, (2) cell lysis, and (3) DNA purification. In these steps there is a trade-off between yield and purity. Physical separation of cells from complex background material prior to lysis (eg, by differential centrifugation methods ${ }^{117}$ ) can improve purity. However, cell separation methods are time-consuming, and differential centrifugation generally gives poor recovery rates (below $50 \%)^{118}$

The method used for releasing cells from the sampling material has a great impact on the analytical limit of detection. For both $F$. tularensis and B. anthracis cells, centrifuging the sampling material immersed in PBS buffer using the Swab Extraction Tube System (SETS), consisting of an inner tube with a small hole and an outer collection tube, gave a 1 log unit lower limit of detection compared to sonication and vortex procedures. ${ }^{119,120}$ The better 
performance of SETS was verified using nylon flocked swabs, rayon swabs, polyester swabs, and cotton swabs. It was hypothesized that centrifugation provided the most efficient transfer of liquid from the sampling material to the extraction tube.

Cell lysis can be achieved using various approaches: chemical (eg, applying detergents), enzymatic (eg, applying proteinases), physical (eg, heating), or mechanical (eg, bead-beating). Combining 2 or more of these (eg, heating and proteinase $\mathrm{K}$ treatment) can elevate the lysis efficiency. Following lysis, PCR-inhibitory substances co-extracted with DNA need to be handled. Preferably, this should be done by customizing the DNA polymerase-buffer system as described above. Otherwise, extensive DNA purification is often needed, ${ }^{114,121,122}$ leading to DNA loss. ${ }^{23,123}$ The degree of loss depends on both sample type and purification method. Recovery rates from about $10 \%$ to $85 \%$ have been reported when comparing different purification principles and methods for a certain sample type. ${ }^{23,124}$ It is necessary to choose wisely when applying commercial DNA extraction/purification kits for biological samples of limited amount and purity. In a comparison among 5 extraction kits for detection of $F$. tularensis spiked in soil samples, the limit of detection differed up to 3 log units between the best and the worst kit. ${ }^{125}$ As most kits have undisclosed contents to some extent, it is difficult to know whether a specific purification kit would work for a specific sample type without testing it.

Nonlinear electrophoresis applying synchronous coefficient of drag alteration (SCODA) is a promising new tool for DNA purification for complex environmental samples, as shown for plants and soils. ${ }^{126,127}$ There, DNA is concentrated and separated from impurities by changing the direction and amplitude of the voltage over an agarose gel. SCODA was shown to remove humic acids more efficiently than other available purification techniques and kits, including direct current electrophoresis, chromatography, and PowerSoil DNA isolation kit. ${ }^{127}$ The reported recovery rates span from $38 \%$ to $73 \%$, with differences between different soil types. ${ }^{126,127}$ Considering the extra work, cost, and DNA loss, SCODA, as well as other purification methods, should be applied only when the downstream analysis demands it - that is, when the best possible DNA polymerase-buffer system fails due to impurities.

\section{Automation and Point-of-Care Analysis}

Automation of nucleic acid purification with homogeneous extract as starting material is quite straightforward. There are several commercially available systems, most based either on DNA binding magnetic beads or spin columns. ${ }^{128-130}$ For cell samples on filter paper, such as FTA, it is easy to set up an automated analysis chain where PCR is performed on paper discs and DNA extraction/ purification is not needed. ${ }^{131}$ Automating cell elution and lysis for large, heterogeneous samples with low amounts of target cells, as in forensic DNA analysis and bioterrorism preparedness, is more difficult and currently not possible using any validated robotic systems. In order to optimize limit of detection and speed of analysis, it is advisable to automate the post-lysis procedures, or nucleic acid purification (if needed after optimizing the inhibitortolerance of the DNA polymerase-buffer system), PCR/ qPCR setup, and post-PCR analysis setup. Cell elution and lysis can instead be simplified and improved by reducing manual handling and the number of tube transfers. Quick 1-tube DNA extraction procedures, such as a method based on EA1 proteinase, ${ }^{132,133}$ will probably form an important base for efficient sample processing in the future. Dedicated research is needed to make these types of quick sample treatment methods more efficient, both regarding throughput and analytical limit of detection.

The development of efficient analysis procedures in bioterrorism preparedness should preferably go in 2 directions. First, central laboratories with special facilities for handling bioterrorism agents in a safe manner are needed to build up cost-effective, automated, highthroughput analysis chains for various microbial targets. There the bulk of the samples are analyzed-for example, if several farms must be investigated to confirm the presence or absence of $B$. anthracis in the wake of an outbreak. Second, mobile point-of-care analysis systems are needed to provide quick results on the site of an outbreak. Labon-a-chip (or, so far, rather lab-on-a-truck) solutions can be applied. Miniaturized PCR-based analysis systems for detection of pathogens have been developed, using real-time fluorescence measurements ${ }^{134}$ and integrated capillary electrophoresis separation. ${ }^{135}$ However, the bottleneck for lab-on-a-chip-based analysis is turning a large heterogeneous sample into a highly concentrated nucleic acid extract that fits into nanoliter-scale analysis. Development of sampling and sample treatment methods suitable for lab-on-a-chip applications is therefore a major challenge in developing truly usable biopreparedness point-of-care analysis systems.

\section{Conclusions}

Diagnostic PCR plays an important part in the detection of biothreat agents because of its high specificity and low limit of detection. Pre-PCR processing is the concept of viewing sampling, sample treatment, and the chemical composition of PCR as an integrated chain and, preferably, optimizing all these steps in one combined study. A cornerstone in pre-PCR processing is to apply inhibitor-tolerant DNA polymerase-buffer systems, thereby reducing the need for extensive DNA purification where DNA is lost.

It is vital to improve the awareness about pre-PCR processing issues among LRNs involved in agroterrorism and bioterrorism preparedness, in order to enable 
streamlined analysis processes, efficient troubleshooting, trustworthy quality control, and an optimal analytical success rate. Implementation of pre-PCR processing validated protocols will improve the diagnostic capability of LRNs. This is crucial since diagnostic PCR is applied to detect low levels of biothreat agents in various PCR inhibitory samples. Applying pre-PCR processing principles in the optimization of biopreparedness DNA analysis chains ensures reliable data for decision makers involved in a bioterrorism incident.

\section{ACKNOWLedgments}

The writing of this article was supported by grants from the Swedish Civil Contingencies Agency (Anslag 2:4 Krisberedskap) and was performed in the framework of the EU project AniBioThreat (Grant Agreement: Home/2009/ ISEC/AG/191) with financial support from the Prevention of and Fight against Crime Programme of the European Union, European Commission-Directorate General Home Affairs. This publication reflects the views only of the authors, and the European Commission cannot be held responsible for any use that may be made of the information contained therein.

\section{REFERENCES}

1. Henderson DA. The looming threat of bioterrorism. Science 1999;283(5406):1279-1282.

2. Wheelis M, Casagrande R, Madden LV. Biological attack on agriculture: low-tech, high-impact bioterrorism. BioScience 2002;52:569-576.

3. Knutsson R, van Rotterdam B, Fach P, et al. Accidental and deliberate microbiological contamination in the feed and food chains-how biotraceability may improve the response to bioterrorism. Int J Food Microbiol 2011;145 Suppl 1:S123-S128.

4. Lim DV, Simpson JM, Kearns EA, Kramer MF. Current and developing technologies for monitoring agents of bioterrorism and biowarfare. Clin Microbiol Rev 2005; 18(4):583-607.

5. Knutsson R. Diagnostic bioterrorism response strategies. In: Morse SA, editor. Bioterrorism USA. InTech; 2012.

6. Morse SA, Kellogg RB, Perry S, et al. The laboratory response network. In: Kocik J, Janiak M, Negut M, eds. Preparedness Against Bioterrorism and Re-emerging Infectious Diseases. Amsterdam, Netherlands: IOS Press; 2004:26-36.

7. Wagar EA, Mitchell MJ, Carroll KC, et al. A review of sentinel laboratory performance: identification and notification of bioterrorism agents. Arch Pathol Lab Med 2010; 134(10):1490-1503.

8. Australian Society for Infectious Diseases; Bioterrorism Response Advisory Group. Microbiology Australia. Editorial. Melbourne: Australian Society for Microbiology; 2004:25-46.
9. Chemical, Biological, Radiological-Nuclear and Explosives Reserach and Technology Initiative. Annual report 20062007, Canadian Reserach and Technology Initiative, Canada. 2007.

10. Binder P. French National Network of Biotox-Piratox laboratories: a network of integrated networks to address the need for analyses in the event of a terrorist threat. EuroReference 2012; 7:17-21.

11. Hwang HS. The strategic plan for preparedness and response to bioterrorism in Korea. J Prev Med Public Health 2008;4:209-213.

12. Holmdahl L, Granelli K, Lorentzon P, Danielsson C, Knutsson R, Myrén S. Identifiering av larmvägar i händelse av avsiktlig smittspridning, biokriminalitet och bioterrorism. SVA:s rapportserie 17. Swedish Veterinary Institute; 2011.

13. Morse SA, Kellogg RB, Perry S, et al. Detecting biothreat agents: the laboratory response network. ASM News 2003;9:433-437.

14. Versage JL, Severin DDM, Chu MC, Petersen JM. Development of a multitarget real-time TaqMan PCR assay for enhanced detection of Francisella tularensis in complex specimens. J Clin Microbiol 2003;41(12):5492-5499.

15. Bell CA, Uhl JR, Hadfield TL, et al. Detection of Bacillus anthracis DNA by LightCycler PCR. J Clin Microbiol 2002;40(8):2897-2902.

16. Espy MJ, Cockerill FR, Meyer RF, et al. Detection of smallpox virus DNA by LightCycler PCR. J Clin Microbiol 2002;40(6):1985-1988.

17. Kumar S, Tuteja U. Detection of virulence-associated genes in clinical isolates of Bacillus anthracis by multiplex PCR and DNA probes. J Microbiol Biotechnol 2009;19(11): 1475-1481.

18. Yang S, Ramachandran P, Rothman R, et al. Rapid identification of biothreat and other clinically relevant bacterial species by use of universal PCR coupled with highresolution melting analysis. J Clin Microbiol 2009;47(7): 2252-2255.

19. Jacob D, Sauer U, Housley R, et al. Rapid and highthroughput detection of highly pathogenic bacteria by Ibis PLEX-ID technology. PLoS One 2012;7(6):e39928.

20. Cummings CA, Bormann Chung CA, et al. Accurate, rapid and high-throughput detection of strain-specific polymorphisms in Bacillus anthracis and Yersinia pestis by nextgeneration sequencing. Investig Genet 2010;1(1):5.

21. Rådström P, Knutsson R, Wolffs P, Lövenklev M, Löfström C. Pre-PCR processing: strategies to generate PCRcompatible samples. Mol Biotechnol 2004;26(2):133-146.

22. Hedman J, Rådström P. Overcoming inhibition in realtime diagnostic PCR. Methods Mol Biol 2013;943:17-48.

23. Miller DN, Bryant JE, Madsen EL, Ghiorse WC. Evaluation and optimization of DNA extraction and purification procedures for soil and sediment samples. Appl Environ Microbiol 1999;65(11):4715-4724.

24. Abu Al-Soud W, Rådström P. Capacity of nine thermostable DNA polymerases to mediate DNA amplification in the presence of PCR-inhibiting samples. Appl Environ Microbiol 1998;64(10):3748-3753.

25. Abu Al-Soud W, Rådström P. Effects of amplification facilitators on diagnostic PCR in the presence of blood, feces, and meat. J Clin Microbiol 2000;38(12):4463-4470. 
26. Hedman J, Nordgaard A, Rasmusson B, Ansell R, Rådström P. Improved forensic DNA analysis through the use of alternative DNA polymerases and statistical modeling of DNA profiles. Biotechniques 2009;47(5):951-958.

27. Hedman J, Nordgaard A, Dufva C, Rasmusson B, Ansell R, Rådström P. Synergy between DNA polymerases increases polymerase chain reaction inhibitor tolerance in forensic DNA analysis. Anal Biochem 2010;405:192200.

28. Lantz PG, Hahn-Hägerdal B, Rådström P. Sample preparation methods in PCR-based detection of food pathogens. Trends Food Sci Technol 1994;5:384-389.

29. Wilson IG. Inhibition and facilitation of nucleic acid amplification. Appl Environ Microbiol 1997;63(10):37413751.

30. Alaeddini R. Forensic implications of PCR inhibition-A review. Forensic Sci Int Genet 2011;6:297-305.

31. Bessetti J. An introduction to PCR inhibitors. Promega: Profiles in DNA 2007;10(1):9-10.

32. Opel KL, Chung D, McCord BR. A study of PCR inhibition mechanisms using real time PCR. J Forensic Sci 2010;55:25-33.

33. Sutlovic D, Definis Gojanovic M, Andelinovic S, Gugic D, Primorac D. Taq polymerase reverses inhibition of quantitative real time polymerase chain reaction by humic acid. Croat Med J 2005;46(4):556-562.

34. Sutlovic D, Gamulin S, Definis-Gojanovic M, Gugic D, Andjelinovic S. Interaction of humic acids with human DNA: proposed mechanisms and kinetics. Electrophoresis 2008;29(7):1467-1472.

35. Baar C, d'Abbadie M, Vaisman A, et al. Molecular breeding of polymerases for resistance to environmental inhibitors. Nucleic Acids Res 2011;39(8):e51.

36. Bickley J, Short JK, McDowell DG, Parkes HC. Polymerase chain reaction (PCR) detection of Listeria monocytogenes in diluted milk and reversal of PCR inhibition caused by calcium ions. Lett Appl Microbiol 1996;22(2): 153-158.

37. Tebbe CC, Vahjen W. Interference of humic acids and DNA extracted directly from soil in detection and transformation of recombinant DNA from bacteria and a yeast. Appl Environ Microbiol 1993;59(8):2657-2665.

38. Abu Al-Soud W, Jönsson LJ, Rådström P. Identification and characterization of immunoglobulin $\mathrm{G}$ in blood as a major inhibitor of diagnostic PCR. J Clin Microbiol 2000;38(1):345-350.

39. Gudnason H, Dufva M, Bang DD, Wolff A. Comparison of multiple DNA dyes for real-time PCR: effects of dye concentration and sequence composition on DNA amplification and melting temperature. Nucleic Acids Res 2007;35:e127.

40. Horakova H, Polakovicova I, Shaik GM, et al. 1,2-propanediol-trehalose mixture as a potent quantitative real-time PCR enhancer. BMC Biotechnol 2011;11:41.

41. Burkhart CA, Norris MD, Haber M. A simple method for the isolation of genomic DNA from mouse tail free of realtime PCR inhibitors. J Biochem Biophys Methods 2002;52(2):145-149.

42. Zipper H, Buta C, Lammle K, Brunner H, Bernhagen J, Vitzthum F. Mechanisms underlying the impact of humic acids on DNA quantification by SYBR Green I and con- sequences for the analysis of soils and aquatic sediments. Nucleic Acids Res 2003;31(7):e39.

43. Wadowsky RM, Laus S, Libert T, States SJ, Ehrlich GD. Inhibition of PCR-based assay for Bordetella pertussis by using calcium alginate fiber and aluminum shaft components of a nasopharyngeal swab. J Clin Microbiol 1994;32(4):1054-1057.

44. Abu Al-Soud W, Ouis IS, Li DQ, Ljungh A, Wadström T. Characterization of the PCR inhibitory effect of bile to optimize real-time PCR detection of Helicobacter species. FEMS Immunol Med Microbiol 2005;44(2):177-182.

45. Lantz PG, Matsson M, Wadström T, Rådström P. Removal of PCR inhibitors from human faecal samples through the use of an aqueous two-phase system for sample preparation prior to PCR. J Microbiol Methods 1997;28(3):159-167.

46. Rossen L, Norskov P, Holmstrom K, Rasmussen OF. Inhibition of PCR by components of food samples, microbial diagnostic assays and DNA-extraction solutions. Int J Food Microbiol 1992;17(1):37-45.

47. Burgess LC, Hall JO. UV light irradiation of plastic reaction tubes inhibits PCR. Biotechniques 1999;27(2):252-256.

48. Fox DH, Huang CK, Du J, Chang TY, Pan Q. Profound inhibition of the PCR step of CF V3 multiplex PCR/OLA assay by the use of UV-irradiated plastic reaction tubes. Diagn Mol Pathol 2007;16(2):121-123.

49. Tamariz J, Voynarovska K, Prinz M, Caragine T. The application of ultraviolet irradiation to exogenous sources of DNA in plasticware and water for the amplification of low copy number DNA. J Forensic Sci 2006;51(4):790-794.

50. Abu Al-Soud W, Rådström P. Purification and characterization of PCR-inhibitory components in blood cells. J Clin Microbiol 2001;39(2):485-493.

51. Akane A, Matsubara K, Nakamura H, Takahashi S, Kimura $K$. Identification of the heme compound copurified with deoxyribonucleic acid (DNA) from bloodstains, a major inhibitor of polymerase chain reaction (PCR) amplification. J Forensic Sci 1994;39(2):362-372.

52. Belec L, Authier J, Eliezer-Vanerot MC, Piedouillet C, Mohamed AS, Gherardi RK. Myoglobin as a polymerase chain reaction (PCR) inhibitor: a limitation for PCR from skeletal muscle tissue avoided by the use of Thermus thermophilus polymerase. Muscle Nerve 1998;21(8):1064-1067.

53. Katcher HL, Schwartz I. A distinctive property of Tth DNA polymerase: enzymatic amplification in the presence of phenol. Biotechniques 1994;16(1):84-92.

54. Thornton CG, Passen S. Inhibition of PCR amplification by phytic acid, and treatment of bovine fecal specimens with phytase to reduce inhibition. J Microbiol Methods 2004;59(1):43-52.

55. Monteiro L, Bonnemaison D, Vekris A, et al. Complex polysaccharides as PCR inhibitors in feces: Helicobacter pylori model. J Clin Microbiol 1997;35(4):995-998.

56. Kreader CA. Relief of amplification inhibition in PCR with bovine serum albumin or T4 gene 32 protein. Appl Environ Microbiol 1996;62(3):1102-1106.

57. Tsai YL, Olson BH. Rapid method for separation of bacterial DNA from humic substances in sediments for polymerase chain reaction. Appl Environ Microbiol 1992;58(7):2292-2295.

58. Tsai YL, Olson BH. Detection of low numbers of bacterial cells in soils and sediments by polymerase chain reaction. Appl Environ Microbiol 1992;58(2):754-757. 
59. Hoorfar J, Cook N, Malorny B, et al. Making internal amplification control mandatory for diagnostic PCR. J Clin Microbiol 2003;41(12):5835-5835.

60. Reiss RA, Rutz B. Quality control PCR: a method for detecting inhibitors of Taq DNA polymerase. Biotechniques 1999;27(5):920-926.

61. Cankar K, Stebih D, Dreo T, Zel J, Gruden K. Critical points of DNA quantification by real-time PCR - effects of DNA extraction method and sample matrix on quantification of genetically modified organisms. BMC Biotechnol 2006;6:37.

62. Tichopad A, Bar T, Pecen L, Kitchen RR, Kubista M, Pfaffl MW. Quality control for quantitative PCR based on amplification compatibility test. Methods 2010;50:308-312.

63. Tichopad A, Bar T. Labonnet Ltd., Jordan Valley, Israel. Assessment of reaction kinetics compatibility between polymerase chain reactions. Patent application US 20090176232 A1. 2009.

64. Bar T, Kubista M, Tichopad A. Validation of kinetics similarity in qPCR. Nucleic Acids Res 2011;40:13951406.

65. Maaroufi Y, de Bruyne JM, Duchateau V, Scheen R, Crokaert F. Development of a multiple internal control for clinical diagnostic real-time amplification assays. FEMS Immunol Med Microbiol 2006;48(2):183-191.

66. Hartman LJ, Coyne SR, Norwood DA. Development of a novel internal positive control for TaqMan based assays. Mol Cell Probes 2005;19(1):51-59.

67. Rodriguez-Lazaro D, Pla M, Scortti M, Monzo HJ, Vazquez-Boland JA. A novel real-time PCR for Listeria monocytogenes that monitors analytical performance via an internal amplification control. Appl Environ Microbiol 2005;71(12):9008-9012.

68. Rosenstraus M, Wang Z, Chang SY, DeBonville D, Spadoro JP. An internal control for routine diagnostic PCR: design, properties, and effect on clinical performance. J Clin Microbiol 1998;36(1):191-197.

69. Hudlow W, Chong M, Swango K, Timken M, Buoncristiani M. A quadruplex real-time qPCR assay for the simultaneous assessment of total human DNA, human male DNA, DNA degradation and the presence of PCR inhibitors in forensic samples: A diagnostic tool for STR typing. For Sci Int Genet 2008;2:108-125.

70. Zipper H, Brunner H, Bernhagen J, Vitzthum F. Investigations on DNA intercalation and surface binding by SYBR Green I, its structure determination and methodological implications. Nucleic Acids Res 2004;32(12):e103.

71. Zahra N, Hadi S, Smith JA, Iyengar A, Goodwin W. Development of internal amplification controls for DNA profiling with the AmpFISTR SGM Plus kit. Electrophoresis 2011;32(11):1371-1378.

72. Hedman J, Ansell R, Nordgaard A. A ranking index for quality assessment of forensic DNA profiles. BMC Res Notes 2010;3(1):290.

73. Debernardi A, Suzanne E, Formant A, Pene L, Dufour AB, Lobry JR. One year variability of peak heights, heterozygous balance and inter-locus balance for the DNA positive control of AmpFlSTR Identifiler STR kit. Forensic Sci Int Genet 2011;5(1):43-49.

74. Knutsson R, Löfström C, Grage H, Hoorfar J, Rådström P. Modeling of 5' nuclease real-time responses for optimiza- tion of a high-throughput enrichment PCR procedure for Salmonella enterica. J Clin Microbiol 2002;40(1):52-60.

75. Wolffs P, Grage H, Hagberg O, Rådström P. Impact of DNA polymerases and their buffer systems on quantitative real-time PCR. J Clin Microbiol 2004;42(1):408-411.

76. Mullis KB, Erlich HA, Gelfand DH, Horn GT, Saiki RK. Cetus Corporation, Emeryville, CA, USA. Process for amplifying, detecting, and/or cloning nucleic acid sequences using a thermostable enzyme. Patent US 4965188. 1990.

77. Pavlov AR, Pavlova NV, Kozyavkin SA, Slesarev AI. Recent developments in the optimization of thermostable DNA polymerases for efficient applications. Trends Biotechnol 2004;22(5):253-260.

78. Cline J, Braman JC, Hogrefe HH. PCR fidelity of Pfu DNA polymerase and other thermostable DNA polymerases. Nucleic Acids Res 1996;24(18):3546-3551.

79. Moretti T, Koons B, Budowle B. Enhancement of PCR amplification yield and specificity using AmpliTaq Gold DNA polymerase. Biotechniques 1998;25(4):716-722.

80. Kebelmann-Betzing C, Seeger K, Dragon S, et al. Advantages of a new Taq DNA polymerase in multiplex PCR and time-release PCR. Biotechniques 1998;24(1):154-158.

81. Scalice ER, Sharkey DJ, Christy Jr. KG, Esders TW, Daiss JL. Eastman Kodak Company, Rochester, NY, USA. DNA amplification with thermostable DNA polymerase and polymerase inhibiting antibody. Patent US 5338671. 1994.

82. Birch DE, Laird WJP, Zoccoli MA. Roche Molecular Systems, Inc., Branchburg, NJ, USA. Nucleic acid amplification using a reversibly inactivated thermostable enzyme. Patent US 5773258. 1998.

83. Eilert KD, Foran DR. Polymerase resistance to polymerase chain reaction inhibitors in bone. J Forensic Sci 2009;54: 1001-1007.

84. Kermekchiev MB, Kirilova LI, Vail EE, Barnes WM. Mutants of Taq DNA polymerase resistant to PCR inhibitors allow DNA amplification from whole blood and crude soil samples. Nucleic Acids Res 2009;37(5):e40.

85. Kermekchiev MB, Barnes WM. DNA polymerase technology, Inc. Use of whole blood in PCR reactions. Patent US 7462475. 2008.

86. Barnes WM. PCR amplification of up to $35-\mathrm{kb}$ DNA with high fidelity and high yield from $\lambda$ bacteriophage templates. Proc Natl Acad Sci USA 1994;91:2216-2220.

87. Cheng S, Fockler C, Barnes WM, Higuchi R. Effective amplification of long targets from cloned inserts and human genomic DNA. Proc Natl Acad Sci USA 1994;91(12):5695-5699.

88. Nishimura N, Nakayama T. Shimadzu Corporation, Kyoto, Japan. Process and reagent for amplifying nucleic acid sequences. Patent US 5935825. 1999.

89. Yang YG, Kim JY, Kim SW, Lee SG. Bioquest Inc., Seoul, Korea. Methods for performing direct enzymatic reactions involving nucleic acid molecules. Patent application US 20090155777 A1. 2009.

90. Nath K, Sarosy JW, Hahn J, Di Como CJ. Effects of ethidium bromide and SYBR Green I on different polymerase chain reaction systems. J Biochem Biophys Methods 2000;42(1-2):15-29.

91. Juen A, Traugott M. Amplification facilitators and multiplex PCR: Tools to overcome PCR-inhibition in DNAgut-content analysis of soil-living invertebrates. Soil Biol Biochem 2006;38(7):1872-1879. 
92. Andreasson H, Allen M. Rapid quantification and sex determination of forensic evidence materials. J Forensic Sci 2003;48(6):1280-1287.

93. Wang MY, Olson $\mathrm{BH}$, Chang JS. Improving PCR and $\mathrm{qPCR}$ detection of hydrogenase A (hydA) associated with Clostridia in pure cultures and environmental sludges using bovine serum albumin. Appl Microbiol Biotechnol 2007;77(3):645-656.

94. Eckhart L, Bach J, Ban J, Tschachler E. Melanin binds reversibly to thermostable DNA polymerase and inhibits its activity. Biochem Biophys Res Commun 2000;271(3):726-730.

95. Powell HA, Gooding CM, Garrett SD, Lund BM, McKee RA. Proteinase inhibition of the detection of Listeria monocytogenes in milk using the polymerase chain reaction. Lett Appl Microbiol 1994;18:59-61.

96. Zhang Z, Kermekchiev MB, Barnes WM. Direct DNA amplification from crude clinical samples using a PCR enhancer cocktail and novel mutants of Taq. J Mol Diagn 2010;12(2):152-161.

97. Ahokas H, Erkkila MJ. Interference of PCR amplification by the polyamines, spermine and spermidine. PCR Methods Appl 1993;3(1):65-68.

98. Hodges LR, Rose LJ, Peterson A, Noble-Wang J, Arduino MJ. Evaluation of a macrofoam swab protocol for the recovery of Bacillus anthracis spores from a steel surface. Appl Environ Microbiol 2006;72(6):4429-4430.

99. Buttner MP, Cruz P, Stetzenbach LD, Cronin T. Evaluation of two surface sampling methods for detection of Erwinia herbicola on a variety of materials by culture and quantitative PCR. Appl Environ Microbiol 2007;73(11):3505-3510.

100. Buttner MP, Cruz P, Stetzenbach LD, Klima-Comba AK, Stevens VL, Emanuel PA. Evaluation of the Biological Sampling Kit (BiSKit) for large-area surface sampling. Appl Environ Microbiol 2004;70(12):7040-7045.

101. Brown GS, Betty RG, Brockmann JE, et al. Evaluation of a wipe surface sample method for collection of Bacillus spores from nonporous surfaces. Appl Environ Microbiol 2007;73(3):706-710.

102. Brown GS, Betty RG, Brockmann JE, et al. Evaluation of rayon swab surface sample collection method for Bacillus spores from nonporous surfaces. J Appl Microbiol 2007; 103(4):1074-1080.

103. E2458-10: Standard Practices for Bulk Sample Collection and Swab Sample Collection of Visible Powders Suspected of Being Biothreat Agents from Nonporous Surfaces. West Conshohocken, PA: ASTM International; 2010.

104. E2770-10: Standard Guide for Operational Guidelines for Initial Response to a Suspected Biothreat Agent. West Conshohocken, PA: ASTM International; 2010.

105. Knutsson R, Rådström P. Detection of pathogenic Yersinia enterocolitica by a swab enrichment PCR procedure. Methods Mol Biol 2003;216:311-324.

106. International standard ISO/FDIS 17604: Microbiology of food and animal feeding stuffs -Carcass sampling for microbiological analysis. 2003.

107. Hall D, Fairley M. A single approach to the recovery of DNA and firearm discharge residue evidence. Sci Justice 2004;44(1):15-19.

108. Gunnarsson J, Eriksson H, Ansell R. Success rate of a forensic tape-lift method for DNA recovery. Problems of Forensic Sciences 2010;83:243-254.

109. Bright JA, Petricevic SF. Recovery of trace DNA and its application to DNA profiling of shoe insoles. Forensic Sci Int 2004;145(1):7-12.
110. Barash M, Reshef A, Brauner P. The use of adhesive tape for recovery of DNA from crime scene items. J Forensic Sci 2010;55(4):1058-1064.

111. Li RC, Harris HA. Using hydrophilic adhesive tape for collection of evidence for forensic DNA analysis. J Forensic Sci 2003;48(6):1318-1321.

112. Buttner MP, Cruz P, Stetzenbach LD, Klima-Comba AK, Stevens VL, Cronin TD. Determination of the efficacy of two building decontamination strategies by surface sampling with culture and quantitative PCR analysis. Appl Environ Microbiol 2004;70(8):4740-4747.

113. Hong-Geller E, Valdez YE, Shou Y, Yoshida TM, Marrone BL, Dunbar JM. Evaluation of Bacillus anthracis and Yersinia pestis sample collection from nonporous surfaces by quantitative real-time PCR. Lett Appl Microbiol 2010;50(4): 431-437.

114. Bourke MT, Scherczinger CA, Ladd C, Lee HC. $\mathrm{NaOH}$ treatment to neutralize inhibitors of Taq polymerase. $J$ Forensic Sci 1999;44(5):1046-1050.

115. Fabian P, McDevitt JJ, Houseman EA, Milton DK. Airborne influenza virus detection with four aerosol samplers using molecular and infectivity assays: considerations for a new infectious virus aerosol sampler. Indoor Air 2009;19(5):433-441.

116. Fykse EM, Langseth B, Olsen JS, Skogan G, Blatny JM. Detection of bioterror agents in air samples using real-time PCR. J Appl Microbiol 2008;105(2):351-358.

117. Lantz PG, Abu al-Soud W, Knutsson R, Hahn-Hägerdal B, Rådström P. Biotechnical use of polymerase chain reaction for microbiological analysis of biological samples. Biotechnol Annu Rev 2000;5:87-130.

118. Roose-Amsaleg CL, Garnier-Sillam E, Harry M. Extraction and purification of microbial DNA from soil and sediment samples. Appl Soil Ecol 2001;18:47-60.

119. Walker RE, Petersen JM, Stephens KW, Dauphin LA. Optimal swab processing recovery method for detection of bioterrorism-related Francisella tularensis by real-time PCR. J Microbiol Methods 2010;83(1):42-47.

120. Dauphin LA, Marston CK, Bhullar V, et al. Swab protocol for rapid laboratory diagnosis of cutaneous anthrax. J Clin Microbiol 2012;50(12):3960-3967.

121. Akane A, Shiono H, Matsubara K, Nakamura H, Hasegawa M, Kagawa M. Purification of forensic specimens for the polymerase chain reaction (PCR) analysis. J Forensic Sci 1993;38(3):691-701.

122. Shutler GG, Gagnon P, Verret G, et al. Removal of a PCR inhibitor and resolution of DNA STR types in mixed human-canine stains from a five year old case. J Forensic Sci 1999;44(3):623-626.

123. Hedman J, Dufva C, Norén L, Ansell C, Albinsson L, Ansell R. Applying a PCR inhibitor tolerant DNA polymerase blend in forensic DNA profiling. Forensic Sci Int Genet Supplement Series 2011;3:e349-e350.

124. Norén L, Hedell R, Ansell R, Hedman J. Purification of crime scene DNA extracts using centrifugal filter devices. Investig Genet 2013;4:8.

125. Whitehouse CA, Hottel HE. Comparison of five commercial DNA extraction kits for the recovery of Francisella tularensis DNA from spiked soil samples. Mol Cell Probes 2007;21(2):92-96.

126. Schmedes S, Marshall P, King JL, Budowle B. Effective removal of co-purified inhibitors from extracted DNA 
samples using synchronous coefficient of drag alteration (SCODA) technology. Int J Legal Med 2013;127(4):749755.

127. Engel K, Pinnell L, Cheng J, Charles TC, Neufeld JD. Nonlinear electrophoresis for purification of soil DNA for metagenomics. J Microbiol Methods 2012;88(1):35-40.

128. Anslinger K, Bayer B, Rolf B, Keil W, Eisenmenger W. Application of the BioRobot EZ1 in a forensic laboratory. Leg Med (Tokyo) 2005;7(3):164-168.

129. Nagy M, Otremba P, Kruger C, et al. Optimization and validation of a fully automated silica-coated magnetic beads purification technology in forensics. Forensic Sci Int 2005; 152(1):13-22.

130. Greenspoon SA, Ban JD, Sykes K, et al. Application of the BioMek 2000 Laboratory Automation Workstation and the DNA IQ System to the extraction of forensic casework samples. J Forensic Sci 2004;49(1):29-39.

131. Hedman J, Albinsson L, Ansell C, et al. A fast analysis system for forensic DNA reference samples. Forensic Sci Int Genet 2008;2:184-189.

132. Moss D, Harbison SA, Saul DJ. An easily automated, closedtube forensic DNA extraction procedure using a thermostable proteinase. Int J Legal Med 2003;117(6):340-349.

133. Lounsbury JA, Coult N, Miranian DC, et al. An enzymebased DNA preparation method for application to forensic biological samples and degraded stains. Forensic Sci Int Genet 2012;6(5):607-615.

134. Hua Z, Rouse JL, Eckhardt AE, Srinivasan V, Pamula VK, Schell WA, Benton JL, Mitchell TG, Pollack MG. Multiplexed real-time polymerase chain reaction on a digital microfluidic platform. Anal Chem 2010;82(6):2310-2316.

135. Beyor N, Yi L, Seo TS, Mathies RA. Integrated capture, concentration, polymerase chain reaction, and capillary electrophoretic analysis of pathogens on a chip. Anal Chem 2009;81(9):3523-3528.

136. Khan G, Kangro HO, Coates PJ, Heath RB. Inhibitory effects of urine on the polymerase chain reaction for cytomegalovirus DNA. J Clin Pathol 1991;44(5):360-365.

137. Mahony J, Chong S, Jang D, et al. Urine specimens from pregnant and nonpregnant women inhibitory to amplification of Chlamydia trachomatis nucleic acid by PCR, ligase chain reaction, and transcription-mediated amplification: identification of urinary substances associated with inhibition and removal of inhibitory activity. J Clin Microbiol 1998;36(11):3122-3126.

138. Bej AK, Mahbubani MH, Dicesare JL, Atlas RM. Polymerase chain reaction-gene probe detection of microorganisms by using filter-concentrated samples. Appl Environ Microbiol 1991;57(12):3529-3534.

139. Watanabe Y, Takayama T, Hirata K, et al. DNA typing from cigarette butts. Leg Med (Tokyo) 2003;5(Suppl 1): S177-S179.

140. Lee $A B$, Cooper TA. Improved direct PCR screen for bacterial colonies: wooden toothpicks inhibit PCR amplification. Biotechniques 1995;18(2):225-226.

141. Scholz M, Giddings I, Pusch CM. A polymerase chain reaction inhibitor of ancient hard and soft tissue DNA extracts is determined as human collagen type I. Anal Biochem 1998;259(2):283-286

142. Johnson DW, Pieniazek NJ, Griffin DW, Misener L, Rose JB. Development of a PCR protocol for sensitive detection of Cryptosporidium oocysts in water samples. Appl Environ Microbiol 1995;61(11):3849-3855.

143. Satsangi J, Jewell DP, Welsh K, Bunce M, Bell JI. Effect of heparin on polymerase chain reaction. Lancet 1994; 343(8911):1509-1510.

144. Arezi B, Xing W, Sorge JA, Hogrefe HH. Amplification efficiency of thermostable DNA polymerases. Anal Biochem 2003;321(2):226-235.

145. Gonzalez A, Grimes R, Walsh EJ, Dalton T, Davies M. Interaction of quantitative PCR components with polymeric surfaces. Biomedical Microdevices 2007;9(2):261-266.

146. Arbeli Z, Fuentes CL. Improved purification and PCR amplification of DNA from environmental samples. FEMS Microbiol Lett 2007;272(2):269-275.

147. De Boer SH, Ward LJ, Li X, Chittaranjan S. Attenuation of PCR inhibition in the presence of plant compounds by addition of BLOTTO. Nucleic Acids Res 1995;23(13): 2567-2568.

148. Chang CW, Wang D, Henessy LK. Applied Biosystems. Method for direct amplification from crude nucleic acid samples. Patent application US 20080286772 A1. 2008.

149. Simon MC, Gray DI, Cook N. DNA extraction and PCR methods for the detection of Listeria monocytogenes in coldsmoked salmon. Appl Environ Microbiol 1996;62(3):822-824.

150. Demeke T, Adams RP. The effects of plant polysaccharides and buffer additives on PCR. Biotechniques 1992;12(3): 332-334.

151. Innis MA, Myambo KB, Gelfand DH, Brow MA. DNA sequencing with Thermus aquaticus DNA polymerase and direct sequencing of polymerase chain reaction-amplified DNA. Proc Natl Acad Sci U S A 1988;85(24):9436-9440.

152. Pomp D, Medrano JF. Organic solvents as facilitators of polymerase chain reaction. Biotechniques 1991;10(1):58-59.

153. Sidhu MK, Liao MJ, Rashidbaigi A. Dimethyl sulfoxide improves RNA amplification. Biotechniques 1996;21(1):44-47.

154. Comey CT, Jung JM, Budowle B. Use of formamide to improve amplification of HLA DQ alpha sequences. Biotechniques 1991;10(1):60-61.

155. Spiess AN, Mueller N, Ivell R. Trehalose is a potent PCR enhancer: lowering of DNA melting temperature and thermal stabilization of Taq polymerase by the disaccharide trehalose. Clin Chem 2004;50(7):1256-1259.

156. Kato S, Nishimura N. Shimadzu Coroporation, Kyoto, Japan. Enhancement of nucleic acid amplification by the addition of a polyamine. Patent US 6413747 B1. 2002.

157. Abu Al-Soud W. Optimisation of diagnostic PCR: a study of PCR inhibitors in blood and sample pretreatment [doctoral thesis]. Lund, Sweden: Lund University; 2000.

Manuscript received December 28, 2012, accepted for publication June 18, 2013.

Address correspondence to: Johannes Hedman Lund University Applied Microbiology Getingevägen 60 Lund 22241 Sweden

E-mail: johannes.hedman@tmb.lth.se 